\title{
Queer Politics of Post-Enlightenment: Beyond the Horizon of the Present
}

\author{
Roberto Kulpa, Edinburgh Napier University, UK
}

ABSTRACT | This essay reflects on queer politics in Central and Eastern Europe (CEE) through the examples of Poland and Hungary, using the Derridean concept of "supplement" to expose the inherently unstable and somewhat queer nature of populist nationalisms. I suggest that both populist and LGBTQ+ politics are the legacy of the Enlightenment, consolidating the negative effects of the ongoing dominance (or, more precisely, coloniality) of a European-defined "modernity." In response, I ponder whether the "in-betweenness" of CEE may accelerate the realization of new possibilities for queer politics beyond the heteronormative and racialized present of "Europe."

KEYWORDS | Poland, Hungary, queer politics, logics of supplement, coloniality, Enlightenment

There is a well-known saying in Polish: Polak, Wegier-dwa bratanki, $i$ do szabli, $i$ do szklanki, which translates to "The Pole and Hungarian are two brothers, both [keen on] fighting and drinking." The Hungarian version of the couplet differs slightly, shifting the emphasis from "brotherhood" to "friendship": Lengyel, magyar-két jó barát, együtt harcol s issza borát [the Pole and Hungarian are two good friends, fighting and drinking wine together].

What has recently been happening in front of our eyes is the spectacle of two parties, Hungary's Hungarian Civic Alliance (Fidesz) and Poland's Law and Justice (Prawo i Sprawiedliwość, PiS), waging xenophobic, homophobic, misogynist, and racist wars against minority groups that leave

doi: 10.5325/hungarianstud.48.0.0199

Hungarian Studies Review, Vol. 48, No. 2, 2021

Copyright (C) 2021 The Pennsylvania State University, University Park, PA 
many disgusted. Polish-Hungarian fraternalism has been a popular trope of various scholarly, economic, and political frameworks of "postcommunism" and its geo-temporality (postcommunism is clearly a signifier of both time and place). Moreover, both countries have been used to represent the "progress" of Central and Eastern Europe (CEE) and its neoliberal successes (rather than failures) during the "transition" period starting in the 1980s. ${ }^{1}$ In more recent political vernacular, the coupling of Hungary and Poland in the personages of the respective leaders Viktor Orbán and Jarosław Kaczyński comes to frequently signify the bêtes noires and killjoys of the "golden age" of supposedly peaceful EU-ropean cooperation. ${ }^{2}$ Regardless of the danger in homogenizing the diversity of the two peoples and states and overstating their identities as the (perennial) epitome of "Eastern Europeanness," together they become the new face of the homosocial, manly, friendship-love of Poles and Hungarians. And their politics is defined by the entangled discourses of gender, homosexuality, family, otherness, children, and Christianity.

The broader context of Poland and Hungary's particular conservative gender politics notwithstanding, in the following pages I offer reflections intended to provoke an exchange about what might still become of queer politics in CEE. I explore the cases of Poland and Hungary through the prism of the Derridean concept of "supplement" to expose the inherently unstable and somewhat queer nature of these populist nationalisms. I argue that they are the legacy of the Enlightenment, consolidating the ongoing coloniality of European "modernity." In the concluding section, I ponder whether the "in-betweenness" of CEE may facilitate the realization of imminent possibilities beyond the heteronormative present.

\section{Supplementary Contexts}

There is much to say about the above sayings, notwithstanding the queer intimacies of agitated bonding among ethnic (later "national") peoples: aficionado masculinism, homosocial joviality, and perhaps even the potential for queer love-as "friendship" stems from the -pri- kernel signifying "love" in Proto-Indo-European languages. ${ }^{3}$ When brothers and friends love each other, but their love is no longer kinship-bound and regulated, the queer potential of the Derridean supplement leaks out, spilling itself (un)necessarily. ${ }^{4}$ 
In poststructuralist cosmology, a supplement is an unavoidable element necessary for a core subject to emerge. In logocentric dialecticism, there is no Self without the Other, no subject (or "center," or "original") without an abject ("the periphery," "the queer/fake"), one could say. The supplementary nature of the Other completes and also reveals the lack of and within the "original" (that needs a supplement to achieve completeness). Moreover, supplement presents a threat because it may potentially replace "the original" by playing the role of a substitute for it (because it is compatible with and "like" the original it supplies and supplements). ${ }^{5}$ Such a conceptualization ties in with my understanding of "queer" in this text. "Queer" does not stand for an identity but for a nonaligned transitory state of potentiality, a threshold moment that operates contextually to destabilize the normative sociopolitical order(ing)s, whereby the "social" is predominantly heteronormative. How does it speak to the contemporary politics of sexuality in Hungary and Poland?

As Fidesz and PiS under the respective leadership of Orbán and Kaczyński are characterized by exclusionary, extra/ordinary sociopolitical logics of "emergency" and "threat," so too is the Polish and Hungarian national(ist) love of and for each other unwittingly "too much." Because both men are extra-semantic, porous, and overflowing in their chauvinistic and uncontained agitation of political xenophobia and homophobia, the spectacles they have created too often have turned into pastiche. This, of course, does not mean that their politics is not materially and symbolically dangerous; quite the opposite. The overabundance of political anxiety around migration, gender, and homosexuality in Poland and Hungary reveals fear, which only highlights populists' acknowledgment of the Others' function as a "supplement" to the national(istic) ego. The queer realization here is that despite the supposed posteriority of Others figuring in the national(ist) imagination, the Other is always already present before the self, in this case, the Hungarian and Polish nations as defined by Orbán and Kaczyński. ${ }^{6}$

\section{Present (Im)Perfect}

Bearing in mind the auxiliary concepts from above, let me now explore some examples of how this plays out in practice, starting with the "reforms" of educational systems. In both countries, these "reforms" resulted in the depreciation and (attempted) erasures of, for example, cultural studies 
and gender studies. This has been followed by increased rewards for questionable religious educational establishments coupled with cuts to well-respected institutions, which populist governments attempt to frame as "too liberal." The culmination of these destructive "reforms" were the attempts at the subordination (in Poland) of, and outright attacks (in Hungary) on, the national Academies of Sciences and the effective expulsion of the Central European University from Budapest. ${ }^{8}$ This grave proof of Fidesz and PiS's appetites is further strengthened by another travesty, the case of the public media, which became the governmental propaganda pipeline ${ }^{9}$ that was, as research shows, long in the making in both Hungary ${ }^{10}$ and Poland. ${ }^{11}$

Prefiguring a variety of "civilizational threats" (i.e. feminist or LGBTQ+ activism or scholarship) packed into the fearmongering picklock of "gender ideology," both Fidesz and PiS find themselves in a somewhat twisted love-hate relationship with devils of their own making. There are excellent and numerous works analyzing the genealogies of "anti-genderism" (the term itself is used by gender studies scholars to describe these global movements). ${ }^{12}$ Additionally, Catherine J. Nash and Kath Browne extend these debates with a complimentary concept of "heteroactivism" that highlights these practical and ideological attempts to reinscribe heteronormativity as the dominant logic of societal coherence, which "encompasses but is not beholden to religious tenets and cannot be consistently aligned with any political or cultural movement, as its formulation is historically inflected and place-based." ${ }^{33}$

Furthermore, anti-gender and heteroactivist politics and discourses are a good example of populism, which I understand here as a discursive horizon dividing society into two camps: "the people" (those who perceive themselves as the underdogs, majority-as-minority) and "the elites" (those perceived by the former group as powerful and domineering, the minority-as-majority; the "gender ideology" of feminist and LGBTQ+ activisms/ scholarship). ${ }^{14}$ Populism is-and perhaps needs to be in order to maintain its effectiveness-broad and cannot be foreclosed as a coherent ideology, a program, strategy, or regime. As Chantal Mouffe reminds us, "It is a way of doing politics that can take various ideological forms according to both time and place, and is compatible with a variety of institutional frameworks." ${ }^{15}$ It would be redundant on my part to go into more detail here, as Roman Kuhar and David Paternotte have already offered an excellent analysis of anti-gender populism. ${ }^{16}$ 
For me, what is particularly noteworthy about anti-genderism and heteroactivism as populism is the appreciation of the global dimension and more-than-religious explanations, beyond the usual culprit of the (insert the modifier) Church. In liberal political and academic discourses, populist homophobia (another popular keyword) is very often regionalized to CEE (or other Other regions) and anchored in religion and churches. ${ }^{17}$ While the role of religious institutions is surely important, an overreliance on "church-as-culprit" explanations is not entirely satisfactory to me. While the populism in CEE is obvious, it cannot be confined to one region; this relinks the global-regional in inclusive terms, ousting narratives of CEE exceptionalism that often dominate(d) occidentalist imaginations throughout centuries generally ${ }^{18}$ or more specifically in relation to "sexual modernity." ${ }^{19}$ Furthermore, these global facets are also surfacing in Poland (and perhaps in Hungary and CEE) in another sense. The historic trope of Polonia Antemurale Christianitatis, Poland as the defender of (Christian) Europe from ("infidel") Others, is transmogrified into sex wars waged by traditionalists against modernists. Only now it is not a religion to be fended off; rather "Europe" itself must be shielded from the neoliberal technocracy of Western "modernity," of sexularism. ${ }^{20}$ The "West" is framed as a cultural hegemon forestalling a "true plurality" of ideologies by silencing traditionalists with "politically correct" language and attacking them with "gender ideology."

Trying to conceptualize the Polish and Hungarian political logics of an atavist return to some idealized phantasmagoria of "premodernity" by means of instigating culture wars on a European scale takes me back to the Derridean ideation of the supplement. Could this concept provide an open window through which we might see queer potential overflowing the borders beyond the heteroactivist backlash on the one hand, and feminist and LGBTQ+ activism on the other? I have stated that the adamant presence of "gender ideology" in the imagination and narratives of Fidesz and PiS exposes itself as a supplementary logic. The Others are framed as an extra-majority, yet at the same time, their passionate presence in discourses proves the constitutive necessity of Others, supplying the populist self with its fundamental relationality/relativity.

That is why minorities are perceived as a threat, for as a supplement they remind the heteroactivists and anti-genderists of their inherently unstable claim to "the people." Similarly, I would suggest that the "populist threat" should remind liberals that the claim they lay to "Europe" as synonymous 
with "civilisation" and "modernity" à la Enlightenment, is equally unstable. Fidesz and PiS's antagonistic politics of good and evil is an extra-semantic overexaggeration that only cements the complimentary nature of the normative "us" and queered Others. The relationship between supplementee (receiver; insider; open and porous, thus feminized Polish-Hungarian homosociality) and supplementor (giver; outsider; firm and active, thus masculinized queer Others) bears a twisted logic of heteronormative gender order, but, à rebours, that is queerly.

\section{Idolizing Europe}

There is broad agreement among scholars of gender and sexuality in CEE that culture/sex wars are forms of struggle over the meaning and value-signification of "Europe" in the post-1989, post-2004 world order (irrespective of the national particularisms and local flavors of either feminist and LGBTQ+ or heteroactivist mobilizations). The populist revival feeds on affective attachments spanning from ecstatic to miserable, melancholic to satisfaction, notwithstanding from rage to fear; clearly the supposed rationality of the public and political sphere has withered away (if it ever was there in the first place). This is an important point of reference, a trampoline for future-thinking beyond the horizon of present, indeed, beyond the horizon (of) Europe, modernity, and the Enlightenment.

What do I mean here? The idea of Europe is inseparable from the concepts of "the Enlightenment" and "modernity," founded and constituted through/in the atrocities of coloniality. ${ }^{21}$ Arguably, the Enlightenment crystallized some of the most protuberant concept-practices, idea(l)s, disavowals, and disappointments stitching across and together, but also undoing and tearing apart the contemporary world. As large a topic as the Enlightenment is, my calling upon it here draws on various writings ${ }^{22}$ and claims no fulfilling comprehensiveness. What I do want to highlight can be grouped as follows: (1) scientism in lieu of religion as the organizing cosmology, substituting nature-world-divine-unthinkable with idealization of rationalism and anthropocentrism; (2) invention of the idea of "Europe" as we know it today; (3) genocides of non-European populations benefiting Occidentalism and capitalism; (4) inventing "human rights" for some, while denying the humanity of others; (5) hailing individualism over communitarianism, ditching collaboration and commons for crude utilitarianism 
and liberalism; (6) the objectification of the Earth (the world) as property to be owned and governed by the rational (white European) hu/man agent. $\mathrm{Hu} / \mathrm{man}$ is an effective term here, for "the enunciation of the colonial matrix was founded in two embodied and geo-historically located pillars: the seed for the subsequent racial classification of the planet population and the superiority of white men over men of colour but also over white women." ${ }^{23}$

Against such a background, the ongoing sexual politics of Fidesz and PiS as much as the present variety of feminist and LGBTQ+ counterstrategies all stem from and/or respond to the coloniality of the Enlightenment's foundations for "European modernity." While questioning political liberalism and neoliberal capitalism is nihil novi sub sole, the sexual orientation of Polish-Hungarian politics is a sign of a more foundational break with the liberal consensus that has dominated the Occidental world. This is obnoxiously manifested in the mistrust and disregard for rationality and scientific "truth-claims" ever so clearly presented in the semantic fields of the "post-truth" debates we have been observing in the last several years. ${ }^{24}$

I suggest that the "queer politics beyond the horizon of the present" in the title of this piece should also break with the tradition of the Enlightenment, albeit for different reasons: to reject the legacy of the racial and patriarchal organization of knowledge-making that maintains the colonial matrix of power. Now is the perfect opportunity for feminist and LGBTQ+ scholarship and activisms to "escape into the future" rather than remain in the predominantly reactive mode of counter-balancing the conservative backlash. A more radical horizon needs to be painted-one that fundamentally redraws the "social contract" and the very idea of the "social." I call it "queer politics" in line with the earlier definition of queer (perhaps even queer supplement) as a non-aligned transitory moment that unsettles the current (hetero)normative formations of (European) sociality.

\section{The Speculatively Queer In-Betweenness of CEE}

For a long time, the region's in-betweenness was seen as a hindrance within CEE. On the one hand, through various forms of "nested Orientalisms," 25 self-denigratory discourses of "not being Western enough" have been observed and coupled with a vilifying gaze cast at the "Eastern," which is arguably dragging down progress toward the West. ${ }^{26}$ On the other hand, Occidentalist discourses from without $\mathrm{CEE}$ frame(d) the region as backward. ${ }^{27}$ 
While the intensity of these logics fluctuates periodically, the last several years have definitely seen the inflammation or intensification of "civilizing" discourses again due to the divisive, belligerent politics of Fidesz and PiS as they wage cultural sex wars.

Rather than meditate on the above contradictions, which other scholars have already addressed, as a conclusion I prefer to ask: Can this slippery slope of being neither here nor there actually be a source of the empowering, disruptive location for contemporary queer (geo)politics? Audre Lorde once famously wrote that the master's tools will never dismantle the master's house. But I would add that equally complete estrangement is unproductive, for the labor may be wasted on a task that has little to no effect. To prompt change, one needs to be familiar with the house, to know its structural weaknesses in order to press for alterations, yet not be part of the household set to be disassembled. Could the ambivalent geo-temporalities of CEE be for once a source of advantage that facilitates a movement beyond the legacies of the Enlightenment and Occidentalism?

How can this in-betweenness of CEE, its queer supplementarity and its threshold porosity, geo-temporal ( $t$ )here, which is neither now nor then, be used? I don't have an (easy) answer yet, nor do I think such responsibility should be carried on the shoulders of any one person. I leave this for debate, for the knowledge commons to shape. For now, let us daydream about opening up new speculative spaces for the future perfect: that which will have been, a queer potential beyond the horizon of the present (tense).

ROBERTO KULPA is interested in transnational sexual politics, nationhood, queerness, and nonnormative identities as these are interlocked with discourses of geography and temporality, and EUropeanization. Another area of scholarly interest is the critical epistemologies of knowledge production in social and cultural studies, especially in the contexts of the hegemonic geographies (the "West and the Rest") under neoliberal regimes of "instant truths." Insights from the fields of postcolonial and decolonial as well as cultural translation studies are important here for him. Most recently, Kulpa has been researching "friendship" and developing questions concerning well-being, resilience, and resistance as modi operandi of marginalized groups during precarious times.

NOTES

1. Sabrina P. Ramet, Alternatives to Democracy in Twentieth-Century Europe: Collectivist Visions of Modernity (Budapest: Central European University Press, 2019). 
2. "The Guardian View on Poland and Hungary: Obstacles to Progress ... Again," Guardian, November 17, 2020, https://www.theguardian.com/commentisfree/2020/nov/17/ the-guardian-view-on-poland-and-hungary-obstacles-to-progress-again.

3. Online Etymology Dictionary, s.v. "Friend," https://www.etymonline.com/search?q = Friend (accessed August 30, 2021).

4. Robert Bernasconi, "Supplement," in Jacques Derrida: Key Concepts, ed. Claire Colebrook (London: Routledge, 2015), 19-22.

5. Hui-Yu Huang, “迂迴, 延宕與延異: 《明信片》的書信特質” [Detour, deferral, and différance: epistolarity in the post card] (PhD diss., National Chengchi University, Taipei, 2004), http://thesis.lib.nccu.edu.tw/record/\#Goo89551004.

6. See also Roberto Kulpa, “On Attachment and Belonging: Or Why Queers Mourn Homophobic?, Sexualities 17, no. 7 (2014): 781-801.

7. Patryk Strzałkowski, "Czarnek punktuje swoich: Pisma teologiczne i związane z KUL premiowane wyżej od światowych publikacji” [Czarnek rewards 'his own' [people]: Teology and KUL-based journals higher rated than world-leading publications], Gazeta Wyborcza, February 12, 2021, https://wiadomosci.gazeta.pl/wiadomosci/7,114883,26782307,czarnekpunktuje-swoich-pisma-teologiczne-i-zwiazane-kul-premiowane.html.

8. Anton Ambroziak, "Błyskawiczna wojna z gender studies: Orban bardzo chce być idolem światowej prawicy" [Blitzkrieg against gender studies: Orban wants to be an idol of the Global Right], OKO.press, October 27, 2018, https://oko.press/wojna-z-gender-studies -orban-utrwala-wizerunek-lidera-prawicowej-kontrrewolucji-i-rozgrywa-spor-z-ue/.

9. Zselyke Csaky, "Dał im przykład Orban: Pokazujemy, jak PiS może zmienić polskie media" [Orban has paved them the way: we show how PiS may change Polish media], OKO.press, July 16, 2020, https://oko.press/pokazujemy-jak-pis-bedzie-chcial-zmienicpolskie-media/.

10. Attila Bátorfy and Ágnes Urbán, "State Advertising as an Instrument of Transformation of the Media Market in Hungary," East European Politics 36, no. 1 (2020), 44-65, https:// doi.org/10.1080/21599165.2019.1662398.

11. Roberto Kulpa, "National Menace: Mediating Homo/Sexuality and Sovereignty in the Polish National/ist Discourses," Critical Discourse Studies 17, no. 3 (2020), 327-43, https:// doi.org/10.1080/17405904.2019.1584578.

12. Among others, see Roman Kuhar and David Paternotte, eds., Anti-Gender Campaigns in Europe: Mobilizing Against Equality (London: Rowman \& Littlefield International, 2017); Sonja A. Strube, Rita Perintfalvi, Raphaela Hemet, Miriam Metze, and Cicek Sahbaz, eds., Anti-Genderismus in Europa: Allianzen von Rechtspopulismus und religiösem Fundamentalismus; Mobilisierung_Vernetzung — Transformation [Anti-genderism in Europe: alliances of right-wing populism and religious fundamentalism; mobilization-connectiontransformation] (Bielefeld: transcript Verlag, 2021).

13. Kath Brown and Catherine J. Nash, "Heteroactivism," lambda nordica 25, no. 1 (2020): 72, https://doi.org/10.34041/ln.v25.616; Catherine J. Nash and Kath Browne, Heteroactivism: Resisting Lesbian, Gay, Bisexual and Trans Rights and Equalities (London: Zed Books, 2020). 14. Ernesto Laclau, On Populist Reason (London: Verso, 2005); Chantal Mouffe, For a Left Populism, e-book ed. (London: Verso, 2018).

15. Mouffe, For a Left Populism, 13.

16. Kuhar and Paternotte, eds., Anti-Gender Campaigns, 13-15. 
17. Marco Derks and Mariecke van den Berg, eds., Public Discourses About Homosexuality and Religion in Europe and Beyond (London: Palgrave Macmillan, 2020), https://doi.org/ 10.1007/978-3-030-56326-4; Srdjan Sremac and R. Ruard Ganzevoort, eds., Religious and Sexual Nationalisms in Central and Eastern Europe: Gods, Gays and Governments

18. Attila Melegh, On the East-West Slope: Globalization, Nationalism, Racism and Discourses on Central and Eastern Europe (Budapest: Central European University Press, 2006); Larry Wolff, Inventing Eastern Europe: The Map of Civilization on the Mind of the Enlightenment (Stanford, CA: Stanford University Press, 1994).

19. Roberto Kulpa and Joanna Mizielińska, eds., De-Centring Western Sexualities: Central and Eastern European Perspectives (Farnham, UK: Ashgate, 2011).

2o. Kulpa, "National Menace." The neologism "sexularism" (sex/uality + secularism) highlights the pivotal role of "sexual acceptance" of gender equality and gay rights, which have become the driving force of modern European secularism.

21. Gurminder K. Bhambra, Rethinking Modernity: Postcolonialism and the Sociological Imagination (London: Palgrave MacMillan, 2007); Anibal Quijano, "Coloniality and Modernity/Rationality," Cultural Studies 21, no. 2 (2007): 168-78, https://doi. org/10.1080/09502380601164353; Madina V. Tlostanova and Walter Mignolo, Learning to Unlearn: Decolonial Reflections from Eurasia and the Americas (Columbus: Ohio State University Press, 2012).

22. Among others, Daniel Carey and Lynn Festa, eds., The Postcolonial Enlightenment: Eighteenth-Century Colonialism and Postcolonial Theory (Oxford: Oxford University Press, 2013); Dipesh Chakrabarty, Provincializing Europe: Postcolonial Thought and Historical Difference (Princeton, NJ: Princeton University Press, 2007); Walter D. Mignolo, The Darker Side of Western Modernity: Global Futures, Decolonial Options (Durham, NC: Duke University Press, 2011); Anthony Pagden, ed., The Idea of Europe: From Antiquity to the European Union (New York: Cambridge University Press, 2002).

23. Walter D. Mignolo, "Coloniality: The Darker Side of Modernity," in Sabina Breitwieser, ed., Modernologies: Contemporary Artists Researching Modernity and Modernism (Barcelona: Museu d'Art Contemporani de Barcelona, 2009), 49.

24. Steve Fuller, Post-Truth: Knowledge as a Power Game (New York: Anthem, 2018).

25. Milica Bakic-Hayden, "Nesting Orientalisms: The Case of Former Yugoslavia," Slavic Review 54, no. 4 (1995): 917-31.

26. Melegh, East-West Slope; Tomasz Zarycki, Ideologies of Eastness in Central and Eastern Europe (London: Routledge, 2014).

27. Kulpa and Mizielińska, eds., De-Centring Western Sexualities; Maria N. Todorova, Imagining the Balkans (New York: Oxford University Press, 1997). 